\title{
Does U.S. Soft Power Have Consequences for U.S. Security? Evidence from Popular Support for Suicide Bombing
}

\author{
Giacomo Chiozza
}

\begin{abstract}
I analyze whether U.S. soft power is consequential for U.S. national security. Specifically, I test whether three dimensions of U.S. soft power, i.e. favorable orientations towards the country, its people, or its policies, helped delegitimize the use of suicide terrorist violence against Americans and Westerners in Iraq. As alternative hypotheses, I assess the impact of three factors commonly invoked to explain suicide terrorist violence: the security consequences of U.S. occupation in Iraq; Muslim identity and religiosity; and U.S. support of Israel. I find that, as soft power theorists would predict, disaffection towards the United States and its people were the strongest predictors of the support for suicide bombing against Americans and Westerners in Iraq.
\end{abstract}

Key Words: soft power, anti-Americanism, suicide bombing, foreign public opinion, statistics

$\mathrm{I}_{\mathrm{e}}^{\mathrm{n}}$ this paper, I address a central debate for the theory and practice of U.S. foreign policy, whether U.S. soft power is consequential for U.S. national security. Is it true, as soft power theorists claim, that high popular standing has security implications because it creates a favorable environment for U.S. policy initiatives and security (Lord 2008; Parmar and Cox 2010; Nye 2011; Berger 2014)? Despite the immense literature it has generated, the empirical footprint of soft power has remained insufficiently investigated (Datta 2009; Atkinson 2010; Goldsmith and Horiuchi 2012; Atkinson 2014). Skeptical voices point to the dearth of evidence to substantiate claims about the security implications of soft

*Giacomo Chiozza (giacomo.chiozza@gmail.com) is an Associate Professor in the Department of Political Science at Vanderbilt University. He the author of Anti-Americanism and the American World Order (Johns Hopkins University Press, 2009). His book, Leaders and International Conflict, with H.E. Goemans, (Cambridge University Press, 2011) won the Joseph Lepgold Book Prize given by Georgetown University. His research has been published in the American Journal of Political Science; the European Journal of International Relations; Pacific Review among others.

I would like to thank Carol Atkinson, Lars Berger, Eli Berman, Ajin Choi, Scott Gartner, Chris Gelpi, Joe Grieco, Ron Hassner, Peter Shane Henne, Marc Hetherington, Miles Khaler, David Laitin, David Lake, Mingyan Li, Zeev Maoz, Aila Matanock, Yonatan Morse, Miko Nincic, Chick Perrow, Scott Sagan, Ken Schultz, Zeynep Somer-Topcu, and John Trylch for comments and suggestions. Mistakes, omissions, and other assorted infelicities are my own responsibility. Data, replication codes and supporting materials are available at http://www.chiozza.or

The Korean J ournal of International Studies Vol.13-1 (April 2015), 207-237.

http://dx.doi.org/10.14731/kjis.2015.04.13.1.207

(c) 2015 The Korean Association of International Studies 
power (Layne 2010; Gray 2011). Krasner and Nau's dissent to the American Political Science Association Taskforce Report on U.S. Standing in World Affairs tellingly questions whether standing has relevant implications for the conduct of U.S. diplomacy (American Political Science Association 2009, accessed on 14 June 2014).

I contribute to this debate by investigating whether U.S. soft power helped delegitimize the use of suicide terrorist violence against Americans and Westerners in Iraq. The sources of social support for suicide bombing serve as an area of investigation to evaluate why, in times of high ideological polarization, ordinary people would sympathize with the methods of the extremists. By focusing on popular reactions to U.S. presence abroad, I evaluate a key parameter affecting the decisions to use military force for regime change and state building, namely the risks that U.S. soldiers and civilians have to bear while deployed in war theaters overseas (U.S. Army/Marine Corps 2007). As Kilcullen (2009, 14) has observed, "[soft power] is a critical enabler for a permissive operating environment...and it is also the prime political component in countering a globalized insurgency."

I study patterns of support for suicide bombing against Americans and Westerners in Iraq among people of Muslim religion that were residing in Jordan, Lebanon and Turkey. I choose these three Middle Eastern countries because they are in the immediate security neighborhood of Iraq. Because of their proximity to Iraq, therefore, the publics of these three countries were not only affected by the spillover effects of U.S. occupation in Iraq, but they were also part of the global audience that terrorist groups sought to influence (Hoffman 2006; Piazza 2008; Yetiv 2011). The year under investigation, 2005, reflects one of the most difficult moments in the U.S. occupation of Iraq, when the security situation for the Iraqis and the U.S. troops bordered on a complete collapse (Ricks 2006). As the Coalition Forces were unable to guarantee order in the face of a mounting insurgency, suicide attacks against Americans and Westerners became part of the tragic reality of the Iraq War and fed into a broader discourse of opposition to the United States.

I also evaluate three alternative hypotheses. Each of these hypotheses links support for suicide attacks against Americans and Westerners to factors commonly invoked to explain suicide terrorism. In particular, I consider: (a) the security consequences of U.S. occupation in Iraq (Pape 2005; Piazza 2008); (b) Muslim identity and religiosity (Stern 2003; Atran 2006); and (c) U.S. support of Israel (Waterbury 2003; Cole 2006).

As expected by the theory of soft power, I find that U.S. standing has implications for U.S. security. Aversion to the United States and the American people were the strongest predictors of the support for suicide bombing attacks against 
Americans and Westerners in Iraq. In particular, in Jordan and Lebanon, two countries where one in every two people approved of suicide bombing attacks against Americans and Westerners in Iraq, disaffection towards the United States and its people had reached such a level that ordinary Muslim people found the use of suicide bombings justifiable. Environments where the United States loses its attractiveness can easily become the breeding ground for more pernicious anti-American ideas. These findings, therefore, support the view that U.S. soft power has security implications because it serves as a bastion against the radicalization of ordinary people into beliefs detrimental to U.S. national security.

\section{BACKGROUND ON SUICIDE TERRORISM}

The topic of suicide terrorism, and international terrorism in general, has attracted large amounts of attention among scholars, pundits, policy-makers as well as the general public (United States Department of State 2004; Bloom 2005; Gambetta 2005; Pape 2005; Pedahzur 2005; Victoroff 2005; Enders and Sandler 2006; Crenshaw 2007; Krueger 2007; Rasler et al. 2007; Piazza 2008; O’Rourke 2009; Choi 2010; Henne 2012). There now exists a solid base of knowledge about perpetrators of suicide terrorist attacks and their organizations. Still, the conditions that lead ordinary people to approve of suicide terrorist tactics are poorly understood (Fair and Shepherd 2006; Crenshaw 2007; Bueno de Mesquita 2007; Tessler and Robbins 2007; Shafiq and Sinno 2010). In a thorough assessment of the literature, Crenshaw $(2007,153)$ summarizes the state of knowledge about the societal support for suicide terrorism in somber terms: "We do not know how much weight to accord each factor or how we might measure them." From this vast literature, I highlight a few themes that inform my analysis of the effects of U.S. soft power on the beliefs of the global audiences that might support suicide attacks against Americans and Westerners in Iraq.

In standard definitions of terrorism, the use of violence is portrayed as an instrument "usually intended to influence an audience." (United States Department of State 2004, xii, accessed on 16 June 2014) The audience referred to in the definitions is predominantly the public and policy-makers in the countries that are victims of terrorist attacks. This is the audience that terrorist groups want to frighten to achieve their goals. This is also the audience that scholars analyze when they evaluate whether the perpetrators of terrorist actions manage to induce a policy change in the target countries or when they evaluate the political and economic consequences of terrorist acts (Pape 2005; Krueger 2007; Gould and Klor 2010). 
But the audience for terrorist attacks can also be seen as the societies in whose name the perpetrators of terrorist actions claim to act. "[This] broader audience consists of Muslims of various stripes," writes Yetiv (2011, 96), "including global radical jihadis, religious nationalists, 3secular Muslims, and also non-Muslims who may share antipathy towards the United States.” As is the case with political parties competing for the publics' support, terrorist groups are organizations that vie for the political and moral backing of their constituents, as well as for their financial and logistic support (Weinberg and Pedahzur 2003). As Pedahzur $(2005,25)$ contends, "the decision to mobilize suicide bombers cannot be implemented without a social environment that approves of this method."

Building upon the model of Cragin and Gerwehr $(2005,59)$, we can distinguish three types of audiences: the terrorist themselves, the radical organizations that support them, and the sympathetic communities in the society at large (see also Simon and Martini 2004/05). In their model, each audience is a potential target for an influence campaign aimed at dissuading terrorist actions. As they argue, "Although U.S. policy-makers might not be able to target the terrorists directly, influence programs that affect radical institutions or sympathetic communities may also have an indirect effect on the attitudes and beliefs of the terrorists." (Cragin and Gerwehr 2005, 59).

Despite its intuitive simplicity, the Cragin and Gerwher model offers a useful insight. Namely, the factors that might lead an individual to perpetrate terrorist actions or to volunteer for a suicide bombing mission are not necessarily the same as the ones that motivate a terrorist group to choose suicide missions among other alternatives; or as the reasons that inform the approval of the broader society or a global audience. From the point of view of a terrorist organization, for example, suicide terrorism poses a dilemma. On the one hand, suicide bombing attacks are, as Pedahzur and Perliger $(2006,2)$ document, "the most efficient way to achieve the highest number of victims." ${ }^{1}$ On the other hand, the organization needs to find operatives that are skilled enough to complete the mission but not so skilled that their deaths would affect the future effectiveness of the terrorist organization itself (Bueno de Mesquita 2005; Pape 2005; Berman and Laitin 2006; Moghadam 2006). A popular contention claims that the dilemma can be solved by recruiting dispossessed or disenfranchised members of the communi-

\footnotetext{
${ }^{1}$ No consensus exists on the effectiveness of suicide bombing, and terrorism in general, in advancing the goals of its perpetrators. Pape $(2005,64)$, for example, argues that "Perhaps the most striking aspect of recent suicide terrorist campaigns is that they are associated with gains for the terrorists' political cause about half the time." Pape's conclusion, however, is challenged by Abrahms (2006); Piazza (2008); Gould and Klor (2010).
} 
ty. But scholars have shown that, despite its popularity in the media and among policy-makers, the thesis that the people who join terrorist organizations are poor or uneducated is inconsistent with the empirical record. Rather, terrorist operatives are mostly educated members of the middle class with degrees in engineering (Hafez 2007; Krueger 2007; Gambetta and Hertog 2009; Lee 2011).

At the level of the general publics, Laitin and Shapiro (2008, 214-217) caution against positing a direct link between societal support for suicide terrorism and the perpetration of suicide missions. While a supportive population arguably facilitates the recruiting of operatives and the foiling of counter-terrorist operations by government forces, protracted campaigns do not necessarily require popular support (Pape 2005, 81-82). The organizations that resort to suicide terrorism are at two ends of the spectrum: they are not only the ones whose constituencies support the adoption of such extreme tactics, but also those that have no roots in the local community and use suicide attacks to intimidate local populations (Kalyvas and Sánchez-Cuenca 2005). ${ }^{2}$

Moreover, under the logic of outbidding, suicide campaigns also generate support for an organization against rival organizations, which in turns serves as a further incentive for more suicide attacks in a cycle of escalating violence (Bloom 2005). In this dynamic, counter-terrorist strategies can also mobilize greater support for suicide terror. In particular, counter-terrorist tactics that do not effectively discriminate between civilian bystanders and specific terrorist targets potentially harden the support for suicide attacks in a tit-for-tat fashion (Bloom 2005, 91).

For the U.S. policy-makers and military planners that have been developing anti-terrorist strategies, this creates a considerable challenge. The factors that lead ordinary people to state their approval of suicide bombing are but one "ingredient," and probably not one that can generate immediate success in thwarting the use of suicide bombing. Strategies that disrupt recruitment and favor defection in terrorist organizations are likely to be more effective in the short term. But, if we need to imagine future threats and counter them before they manifest themselves, it is important to understand the radicalization of beliefs in favor of extreme tactics. The reasons that have given legitimacy to the use of suicide bombing might also serve to justify other extreme tactics, such as the use of loose nuclear weapons or biological agents, in the arsenal of future adversaries of the United States (See Berman and Laitin's contribution in Rasler et al. $(2007,128)$.

\footnotetext{
${ }^{2}$ Moghadam (2006, 103) argues that suicide bombing campaigns in Iraq have targeted the local population in an effort to intimidate, rather than win any local support, which would mark a break from previous campaigns such as those employed in Lebanon, Israel or Sri Lanka.
} 


\section{FOUR HYPOTHESES}

I elaborate four specific hypotheses regarding why ordinary men and women state their approval of suicide bombing against Americans and Westerners in Iraq. The primary hypothesis is the extent to which the publics of Jordan, Lebanon and Turkey oppose suicide attacks against Americans and Westerners in Iraq in light of their views of U.S. soft power. The three alternative hypotheses engage established arguments in the literature regarding the presence of foreign occupiers, Muslim identity and religiosity, and U.S. support of Israel.

\section{THE SOFT POWER THESIS}

The theory of soft power contends that beliefs about the attractiveness of U.S. values and culture and about the legitimacy of U.S. policies create "an enabling or disabling environment for specific policy initiatives." (Nye 2011, 96) In this case, we should expect that people who have favorable orientations towards U.S. soft power would be less inclined to justify suicide attacks against Americans and Westerners in Iraq. The effect of soft power would not be 6direct - from soft power resources to decisions to employ suicide attacks - but indirect. It would operate through public opinion by undermining the broader appeal that the extremists' actions would receive.

As Nye (2011, 94-95) himself admits, public opinion provides a "first approximation" for the effects of soft power on popular perceptions of alternative policies and tactics. But it is an important approximation, in particular in the context of globalized insurgencies (Kilcullen 2009). In a study of public opinion in Egypt, Indonesia, and Pakistan, Berger (2014) finds that negative views of U.S. culture are a strong predictor of support of attacks against civilians in the United States. U.S. military commanders also acknowledge the indirect effects of soft power on the prospects for strategic success in the hybrid conflicts the United States is currently fighting. They admit that the United States cannot prevail in current military engagements by hard power alone (Shanker 2010a). General McChrystal, former commander of U.S. forces in Afghanistan, states it clearly: "This is all a war of perceptions. This is not a physical war in terms of how many people you kill or how much ground you capture, how many bridges you blow up. This is all in the minds of the participants." (Shanker 2010b)

The basic contention of soft power theory, however, has been met with skepticism (Layne 2010; Gray 2011). The connection between favorable views of the United States and opposition to attacks against American people or interests is discounted as the manifestation of pro-U.S. predispositions rather than the expression of a causal relation between soft power and policy beliefs. As an illus- 
tration of this perspective, Gray $(2011,37)$ summarizes his critical assessment of hard and soft power as instruments of policy by stating: "soft power resides in the ability to co-opt the willing rather than to coerce or compel the reluctant;" and, thus, soft power can be at best useful at the margin in the conduct of coercive diplomacy.

The test that I conduct in this study evaluates the impact of soft power on the radicalization of ordinary people at a time, 2005, and in a region, the immediate security neighborhood of Iraq, where anti-American sentiments were predominant. In Gray (2011)'s terms, few people counted as "willing," and many counted as "reluctant." As a consequence, should this hypothesis turn out to be correct, we would have an example of how lack of standing in the eyes of foreign publics might have negative consequences for U.S. security. It would indicate that a decline in U.S. soft power would be a determinant of the radicalization of ordinary people, which, in turn, would foster more worrisome beliefs, such as the belief that the use of suicide violence against Americans and Westerners is justified.

Nye (2011, 84) distinguishes three sources of a country's soft power: "its culture (in places where it is attractive to others), its political values (when it lives up to them at home and abroad), and its foreign policies (when others see them as legitimate and having moral authority)." To track these dimensions, I use three indicators that measure beliefs about the United States, about the American people, and support for U.S. anti-terrorism policy, respectively. The first one, an overall measure of favorable attitudes towards the United States, is the most encompassing, capturing the three sources of soft power in Nye (2011)'s definition simultaneously (Chiozza 2009; Datta 2014). The other two indicators are more specific and are closer to the cultural and policy dimensions of U.S. soft power, respectively.

The indicators are empirically distinct. For example, in Jordan and Lebanon, two countries where around $80 \%$ and $77.8 \%$, respectively, of the public viewed the United States in negative terms, the image of the American people was more "balanced." About two thirds of the Jordanians and about 47.3\% of the Lebanese expressed a negative opinion of the American people. The disjunction between a more positive opinion of the people and a clearly negative opinion of the country, therefore, indicates an admittedly small reservoir of good will and empathy towards the Americans. Similarly, about $49.3 \%$ people with a positive view of the United States were endorsing the U.S. anti-terrorist policy, while $43.5 \%$ were opposing it with the rest expressing no opinion.

The percentage of people with a negative view on all three indicators - the country, the people, and the anti-terror policies - was $66.9 \%$ in Jordan, $46.9 \%$, and $44.4 \%$ in Turkey. Clearly, U.S. standing was low in the minds of many peo- 
ple, but not so much to blur the distinctions between the three dimensions of U.S. soft power captured by these indicators.

\section{THREE ALTERNATIVE HYPOTHESES}

I test three alternative hypotheses to explain support for suicide attacks against Americans and Westerners in Iraq. The first and second alternative hypotheses view support for suicide attacks as a response to the U.S. occupation of Iraq. The third assesses the impact of U.S. support of Israel.

One of the factors most often cited to explain groups' decisions to perpetrate suicide attack is the presence of foreign occupiers (Pape 2005; Crenshaw 2007; Piazza 2008). Occupiers are seen as the "other" that threatens, exploits, and humiliates (Bloom 2005). By their presence, they compromise the physical security of ordinary citizens and their countries. Building upon this insight, I assess the extent to which the publics of countries in the immediate security neighborhood of Iraq, such as Jordan, Lebanon and Turkey, justified the use of suicide attacks as a weapon of the weak to counter the negative effects engendered by U.S. occupation of Iraq. Insofar as they viewed their countries as a potential target of U.S. military intervention, they might have also viewed suicide bombing as an extreme tactic that could constrain a powerful, and allegedly casualty-averse country, such as the United States (Mueller 1971; Gelpi, Feaver and Reifler 2005/o6).

The measurement of this hypothesis is based on a series of indicators that assess people's concerns about the physical security of their countries. Specifically, I measure fear about physical security by identifying the Jordanians, Lebanese and Turks who (a) were very or somewhat worried that the United States could become a military threat to their country; and (b) thought that the removal of Saddam Hussein from power made the world a more dangerous place.

Fear and insecurity engendered by the presence of foreign occupiers can also affect another dimension of people's well-being, which, in line with Mitzen (2006)'s analysis, I call their ontological security. By this, I mean the security ordinary people perceive with respect to their own sense of who they are. This hypothesis contends that the U.S. presence in Iraq and its Middle East policies challenge or insult people's identity as Muslim believers (Stern 2003; Atran 2006). Suicide bombing against Americans and Westerners is then justified as a means to restore the sense of self that U.S. presence and policies allegedly undermine. U.S. officials have emphatically denied any allegation that the United States is at war with Islam; ${ }^{3}$ still the contention of a fundamental opposition between

\footnotetext{
${ }^{3}$ A clear example can be found in President George W. Bush's speech to the General Assembly of
} 
the United States as the bearer of the Western civilization mantle, on the one hand, and the Islamic civilization, on the other, has currency in academic discourse (Huntington 1996), in conservative politics in the United States (Pipes 2002; Rubin 2002), as well as in the propaganda of anti-American terrorists (Juergensmeyer 2003; Stern 2003). Under this hypothesis, therefore, the rhetorical battle to define U.S. anti-terrorist policies since $9 / 11$ has profound implications for the justification of extreme violence against Americans and Westerners.

For the measurement of concerns about ontological security, I identify the Jordanians, Lebanese and Turks who (a) thought that Islam faced serious threats; and (b) thought that Islamic extremism did not pose a relevant threat to their country. These indicators identify the people who thought that Islam was under threat, and were personally comfortable with those aspects of Islam that generate most apprehension in the West. These would be the people who would mostly concerned with their identity as Muslims, i.e. their ontological security, which would then drive their support for suicide bombing.

Finally, the last hypothesis attributes the support for suicide bombing against Americans and Westerners to the resentment against U.S. support of Israel (Waterbury 2003; Cole 2006). Under this hypothesis, suicide attacks against Americans and Westerners are justified as an extreme tactic to make U.S. military and political support of Israel unsustainable. The measurement of such sentiments is obviously difficult, as ordinary people might be wary of openly manifesting their true opinion of other people against what is the perceived societal norm Berinsky (2004). As I report in Figure 1, it is certainly suspicious that not a single Muslim Jordanian or Lebanese stated that they had a positive opinion of Jewish people. It is equally suspicious that not a single Muslim Jordanian or Lebanese had a negative opinion of Muslim people. In the case of Turkey, we find small sections of the population that harbored positive views of Jewish people and negative views of Muslims. As a comparison, views of Christians were mixed (and more balanced) in both Jordan and Lebanon but not in Turkey where only 19.6\% of the population had a favorable opinion of Christians.

the United Nations on September 19th, 2006 (available at http://www.presidentialrhetoric.com/ speeches/o9.19.06.html, accessed on 16 June 2014). 
Figure 1. Opinion of Jews, Christians, and Muslims, 2005
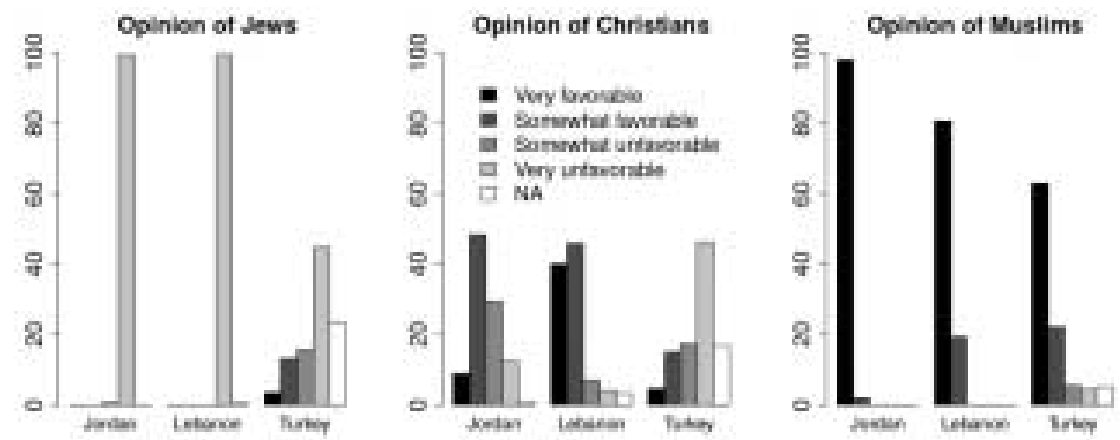

Note: Data analysis is based on the 2005 wave of the Pew Global Attitudes Survey. "NA" stands for not available, don't know, or refused to answer.

To identify the Muslim Jordanians, Lebanese and Turks that might derive their support of suicide bombing from anti-Israeli orientations, therefore, I resort to a different indicator: the belief that Jews have the most pervasive influence on U.S. foreign policy. 4 This indicator captures one of the most pernicious tropes in the antisemitic mindset, the existence of a Jewish cabal, and as such serves a useful purpose in this empirical investigation. Indeed, the view that Jews control U.S. foreign policy was the predominant view in Jordan and Lebanon, where $61 \%$ and $62.5 \%$ of the public held such a view, but not in Turkey where only $17.3 \%$ stated that Jews have the most influence on U.S. foreign policy, a smaller percentage of Turks than the one that attributed the largest influence to the military (21.7\%).5

\section{CONTROL FACTORS}

To test these hypotheses, I control for a variety of factors that might create spurious relations. First, I control for demographic factors: gender, age, education, socioeconomic status, marital status, and family size. Second, I include indicators that measure attitudes towards other countries to evaluate the extent to which it is predominantly attitudes towards the United States that drive attitudes towards

\footnotetext{
${ }^{4}$ The survey item in the Pew Global Attitudes survey offered the following choices for the groups that might influence U.S. foreign policy, with the respective percentage of selection in parenthesis: (a) the news media (8.2\%); (b) business corporations (12.1\%); (c) Jews (44.4\%); (d) Christian conservatives (7\%); (e) the military (10.4\%); (f) liberals (3\%); (g) ordinary Americans (4.1\%); (h) don't know/refused to answer (10.8\%).

${ }^{5}$ A sizable portion of Turks (26.2\%), however, did not express an opinion on the sources of influence on U.S. foreign policy.
} 
suicide attacks against Americans and Westerners in Iraq. I consider attitudes towards France and Germany, two Western countries that took a markedly different approach to the Iraq War. Third, I control for attitudes towards Christians as well as for people's assessment of how important religion is in their lives. These factors help isolate the impact of the beliefs about potential threats to Islam. Finally, I assess whether there are any pro Al-Qaeda sentiments in the population. People who manifest at least some level of confidence in Al-Qaeda's late leader, Usama bin Laden, represent not only the least receptive targets for U.S. soft power, but also the most likely supporters of suicide attacks.

\section{EMPIRICAL STRATEGY}

I rely upon survey data to assess the extent and the sources of popular support for suicide bombing. The data come from a survey conducted on behalf of the Pew Global Attitudes Project in Jordan, Lebanon and Turkey in the spring of 2005. All the respondents who were administered the questions measuring attitudes towards suicide bombing were of Muslim religion. ${ }^{6}$ The Pew Global Attitudes data distinguish three forms of support to suicide terrorism: (a) suicide attacks carried out against Americans and other Western targets in Iraq; (b) suicide attacks carried out to defend Islam with no reference about the location of the attacks; (c) suicide attacks carried out to defend Islam in the country where the people offering their views live. 7

The degree of acceptability of suicide terrorism varies across society and forms. In Figure 2, I report the percentage of respondents that thought suicide bombing and other forms of violence against civilians were viewed as justifiable. In general, large percentages of ordinary people viewed suicide terrorism as never or rarely justifiable regardless of whether the survey experiment explicitly mentioned the location of the attacks. This pattern clearly holds in Turkey where at

\footnotetext{
${ }^{6}$ Sample sizes are 967 respondents in Jordan, 563 in Lebanon and 965 in Turkey. The surveys were collected through face-to-face interviews conducted between April 27, 2005 and May 24, 2005. The surveys are based on a probability sample design, representative of the adult population (18-years old and older) with a $3 \%$ margin of error (Pew Global Attitudes Project 2005). A summary table with the descriptive statistics of all the variables employed in this study is available in the on-line Appendix.

7 The question about suicide attacks against Americans and other Western targets in Iraq was asked only in the 2005 Pew Global Attitudes survey. The last two questions are part of a survey experiment whereby half of the sample was asked the question with no reference to the location of the attacks and half of the sample was asked the question with the specific reference that the attacks would occur in the respondents' countries.
} 
least two thirds of the public rejected suicide terrorism as never justifiable.

Figure 2. Attitudes towards Suicide Bombing, 2005

Is Suicide Bombing Justifiable?
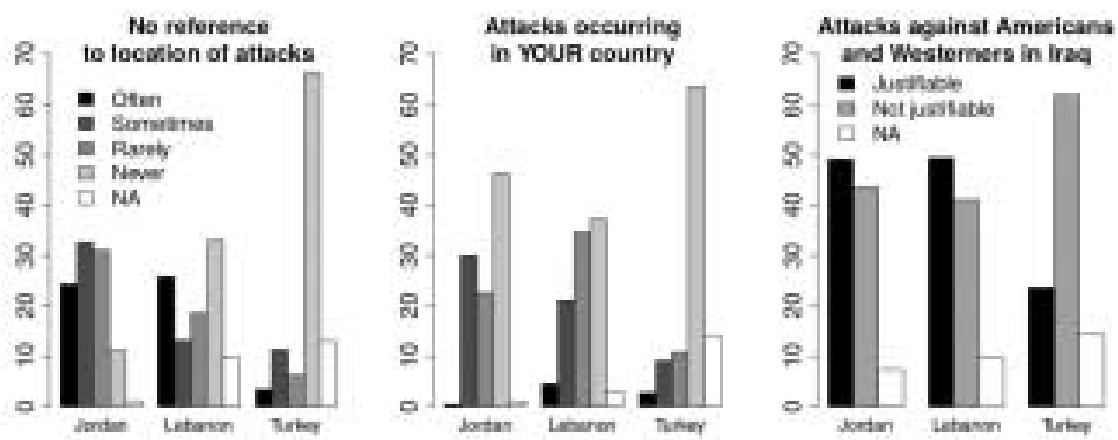

Note: Data analysis is based on the 2005 wave of the Pew Global Attitudes Survey. "NA" stands for not available, don't know, or refused to answer.

The major variation to the pattern of overall rejection of suicide terrorist attacks occurs among the Jordanian and Lebanese publics. There, we observe that attitudes towards terrorism shift dramatically if the publics consider the possibility of attacks in their countries or in general, with no reference to where the attacks occur. Indeed, in Jordan a quarter of the public views suicide terrorism as often justifiable and one third views it as sometimes justifiable. Approval, though, drops if attacks were to occur in Jordan. Nearly half the Jordanian sample opposes suicide attacks against civilians in Jordan. ${ }^{8}$ Lebanese respondents respond in a similar manner, if only less prominently.

When asked about suicide terrorist attacks against Americans and other Western targets in Iraq, however, the general publics split in half and a qualified opposition turned into a qualified approval. As we observe in the right part of Figure 2, public disapproval of suicide attacks against Americans and Westerners was a majoritarian position only in Turkey. In Jordan and Lebanon instead, majorities deemed attacks against the Coalition forces in Iraq justifiable. Clearly, the idea to hurt Americans and Westerners with extreme means was not alien to substantial portions of the public in two Middle Eastern societies.

${ }^{8}$ The survey was taken before the suicide attacks in Amman, which took place on November 9th, 2005. The attacks killed 57 people and injured about 300 (BBC News, 2005, accessed on 16 June 2014). 
In Figure 3, I present a cross-tabulation of the three indicators of public approval of suicide terrorism using fourfold plots. ${ }^{9}$ On the main diagonal in each of the plots, from the upper left general drops about 20 percentage points when they are asked to contemplate the possibility that suicide attacks would be directed against civilians in their country. In Lebanon, a plurality of the general public opposes suicide bombing in their country, but they would be willing to make an exception for American and Western people in Iraq. In general, very few people would condone suicide terrorism as a tactic while disapproving of suicide attacks against Coalition forces in Iraq. It is remarkable, however, that in Lebanon 14\% of the public is ready to justify attacks in their countries but not attacks against Americans and Westerners in Iraq.

Figure 3. Patterns of Support for Suicide Bombing
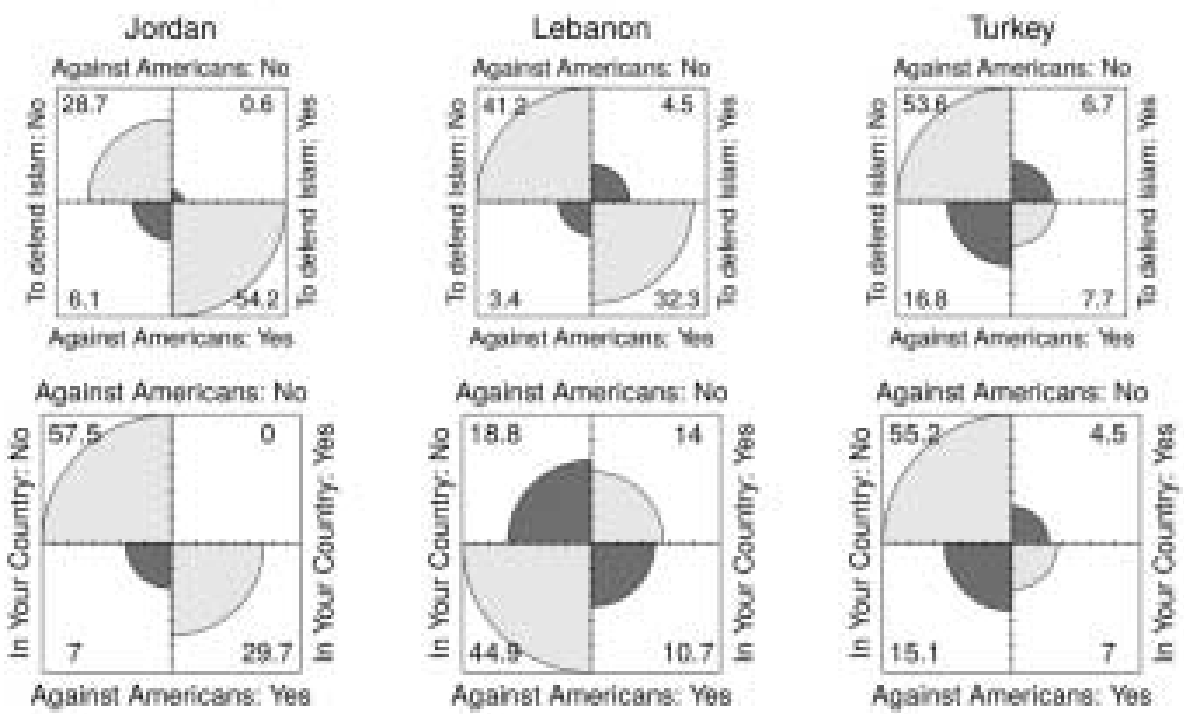

Note: Data analysis is based on the 2005 wave of the Pew Global Attitudes Survey. The numbers in each of the cells represent the percentage of individuals who selected a given combination of responses. The label "Against Americans" is shortened to mean "Against Americans and Westerners." (See also Footnote 9 on page 14 for more details.)

${ }^{9}$ In these graphs the percentage of respondents in each cell of a $2 \times 2$ cross-tabulation is represented by a quarter circle whose radius is proportional to the cell count. For example, in Figure 3, $28.7 \%$ of the Jordanian public disapproved of suicide terrorism to defend Islam in general and against Americans and Westerners in Iraq; o.6\% disapproved of suicide terrorism when carried out against Americans and Westerners in Iraq but thought it was justifiable to defend Islam in general; 54.2\% thought that suicide terrorism was justifiable when carried out against Americans and Westerners 
These patterns confirm the concerns expressed by Fair and Shepherd (2006) and Bueno de Mesquita (2007) about the risks of generalizing findings about suicide attacks. As Berger (2014) has shown, the identity of the targets and the locations of the attacks lead to different findings about the factors that determine popular support for suicide bombing. Therefore, my analysis will focus on attitudes towards attacks against Americans and Westerners in Iraq, because that is the variable with the most direct connection with the argument about soft power. Nonetheless, as a robustness check, I will also assess how the four hypotheses I presented explain attitudes towards suicide attacks perpetrated to defend Islam.

\section{BEYOND REGRESSION: CART MODELS}

To analyze these data, I employ Classification and Regression Tree (CART) models, a class of computational algorithms to classify observations (Therneau and Atkinson 1997, accessed on 16 June 2014; Hastie, Tibshirani and Friedman 2001, 266-279; Berk 2008, 103 -167). These models offer a graphical representation of the most likely combinations of factors that would sustain different views about the justifiability of suicide bombing, which - in the spirit of Tukey (1969)'s "data analysis as detective work" - I can use to adjudicate the four hypotheses in this study. (I describe these models in greater detail in the on-line Appendix.)

A major strength of CART models is the ability to model non-linearities and interactive relations, while avoiding making heroic assumptions about the stochastic processes underlying the data. Regression analysis, the most common modeling approach for survey data, is particularly ill-suited in this respect: even minor violations to the assumption of linear relations lead to erroneous conclusions (Achen 2005). Given current theorizing in terrorism studies, we might expect extensive presence of non-linear relations in the data, which makes CART models a compelling choice in this context. ${ }^{10}$

The final branches in the CART models report how many respondents supported or did not support suicide bombing against Americans and Westerners in Iraq, from which we can infer the overall attitude - i.e., whether the public finds

and to defend Islam in general; and 6.1\% thought that suicide terrorism was justifiable when carried out against Americans and Westerners but not to defend Islam in general. The second row in Figure 3 plots the responses of those who received the survey instrument that specified that the attacks to defend Islam would occur in the respondent's country (Friendly 1999).

${ }^{10}$ Regression analysis is unquestionably a powerful data synthesis technique. Still, the practice of regression modeling is nowadays increasingly questioned (Berk 2004). CART models are one of the approaches recommended by Achen $(2005,337)$ for data with "a variety of statistical regimes in them," i.e. interactive relations. Applications of CART models in political science include Gleditsch and Ward (1997); Kastellec (2010); Chiozza and Choi (2012); Cáceres and Malone (2013). 
suicide bombing justifiable or not - that a given combination of factors on a path is more likely to generate. The labels at the end of the tree ("Yes" and "No") indicate whether a given combination of factors would lead, on average, to a probability of support for suicide bombing greater or lower than $50 \%$, respectively. For ease of interpretation, I employ Bayesian inference to derive probability estimates around these raw numbers (Lee 1997). ${ }^{11}$

I can then assess the extent to which the conditional probabilities of support for suicide bombing measured by the CART models differ from the baseline (unconditional) probability of support. As we would expect, a combination of factors that identify smaller groups yield larger confidence intervals, which indicates greater uncertainty about the estimates and about the representativeness of that particular combination of explanatory factors.

To avoid overfitting the data, I resort to out-of-sample assessments of model performance (de Marchi 2005, 34-77). I use a validation set approach, by splitting the sample randomly in two parts; three quarters of the sample is used as a training sample to "grow the tree;" the remaining one quarter is used to assess the out-of-sample performance of the model (James et al. 2013, Kindle loc: 48154862). As a comparison, I estimate the out-of-sample performance of the most common modeling alternative, logistic models. ${ }^{12}$

\section{FINDINGS}

In Figure 4, I present four CART models, a pooled model for all the three countries, and three disaggregate models for each country. The major finding at the aggregate level, in the upper left panel of Figure 4, is that, positive attitudes towards the United States was the most discriminating factor accounting for opposition to suicide bombing. The probability that someone who had a good opinion of the United States would support suicide attacks was between $4.3 \%$ and 9.1\%, a large drop over the unconditional probability of support which ranged from $41.5 \%$ to $46.2 \%$. As a first result, therefore, the analysis in Figure 4 indicates

${ }^{11}$ The probability that a given individual would support suicide bombing $(\pi)$ can be modeled as a binomial distribution where $\mathrm{n}$ is the number of subjects in the sample and $\mathrm{x}$ is the number of subjects who hold such a belief. I use a non-informative reference prior distribution to derive the posterior distribution and, from that, the probability that the parameter of interest $\pi$ lies in an interval with $95 \%$ probability. I use Jeffrey's reference prior distribution, which has the property of being invariant to scale transformations. In the case of binomial likelihood functions, Jeffrey's prior takes the form of a Beta distribution, $\pi \sim \operatorname{Beta}(1 / 2,1 / 2)$.

${ }^{12}$ I report the logistic regression models in the on-line Appendix. 
that U.S. soft power provided a “disabling environment," as Nye (2011)'s soft power theory predicts.

Figure 4. Attitudinal Profile of the Support for Suicide Bombing against Americans and Westerners
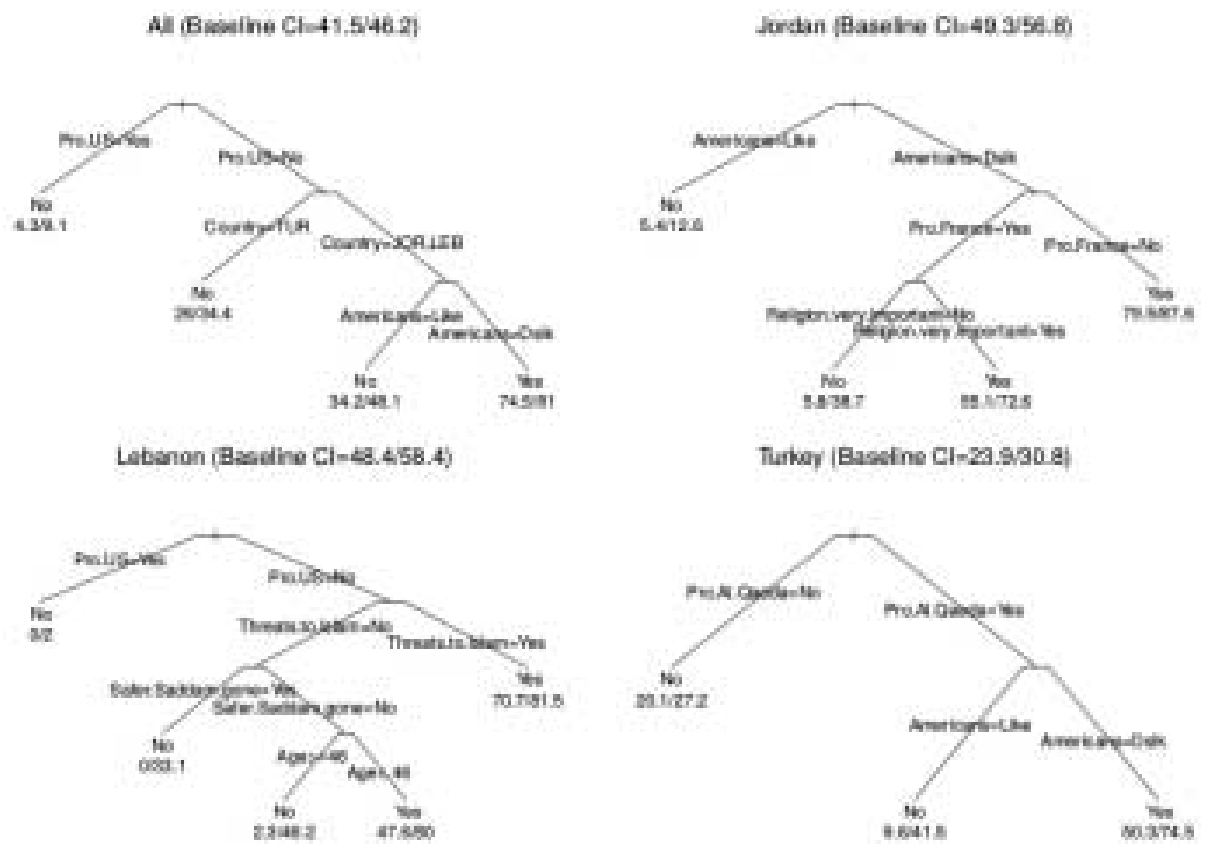

LEGEND:

AMERICANS

PRO.AL.QAEDA

PRO.FRANCE

PRO.US

RELIGION.VERY.IMPORTANT

SAFER.SADDAM.CONE

THREATS.TO.ISLAM

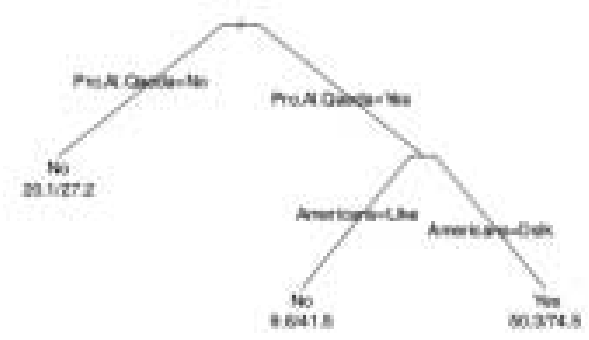

Note: Data analysis is based on the 2005 wave of the Pew Global Attitudes Survey. The labels below the final branches indicate the most common response: "No" indicates that the most common response was disapproval of suicide bombing; "Yes" indicates that the most common response was approval suicide bombing. The numbers underneath measure the $95 \%$ Bayesian confidence intervals around the conditional probability of approval of suicide bombing. "Cl" stands for Confidence Interval.

After that, the model splits the sample separating Turkey, on the one hand, and Jordan and Lebanon, on the other. This split indicates that the patterns in Turkey 
differed from those found in Jordan and Lebanon not just quantitatively, as illustrated in Figures 2 and 3, but also qualitatively. The second substantive factor accounting for patterns of opinion towards suicide attacks was another soft power indicator, i.e. attitudes towards the American people.

For the Jordanians and the Lebanese who disliked the United States, a negative view of the American people increased the probability of approval of suicide attacks against Americans and Westerners to a range between $74.5 \%$ and $81 \%$. For the Jordanians and Lebanese who disliked the United States and liked the Americans, the probability of support for suicide attacks dropped substantially, but not enough to clear the baseline confidence interval.

The country-by-country analysis further validates the aggregate findings. In both the Jordanian and the Lebanese cases, U.S. soft power emerges as the strongest predictor of support for suicide bombing against Americans and Westerners. Overwhelmingly, the Jordanians who had a positive opinion of Americans did not find suicide bombing against them legitimate; the probability interval for the support of suicide attacks ranges from 5.4\% to 12.6\%. Among the Lebanese, no one among those who liked the United States was also willing to justify suicide attacks against them, which yields a probability of support between o\% and $2 \%$.

With such a discriminating power, U.S. soft power emerged as a key factor in structuring opinion towards suicide bombing. Importantly for the theory of soft power, however, its policy component - i.e., the endorsement that foreign publics might give to specific U.S. policies, such as the U.S.-led war on terror - does not emerge as a relevant explanatory parameter. For the people of Jordan, Lebanon, and Turkey, it was the (lack of) normative and personal standing of the United States and its people that would mostly shape their views on anti-American violence.

Beyond the similar effects of U.S. soft power, the patterns in Jordan and Lebanon diverged. In Jordan, we find that attitudes towards France and the importance of religion underlie popular attitudes towards suicide attacks against Americans and Westerners. In the Lebanese case, the second and third most discriminating variables, after the attitudes towards the United States, were two variables measuring two of the alternative hypotheses, namely those concerning Muslim identity and the security consequences of U.S. occupation of Iraq. The combination of a negative view of the United States and the sense that there were serious threats to Islam unsurprisingly pushed the probability of support for suicide attacks to a very high range, between $70.7 \%$ and $81.5 \%$. What is particularly interesting, however, and a finding that CART models powerfully show, is the interaction between one of the soft power variables and two variables measuring 
two of the alternative hypotheses. If we follow the tree branches for Lebanon in Figure 4, we see that beliefs in ontological and physical security, i.e. the beliefs that there were no major threats to Islam and that the world was safer after Saddam Hussein's removal from power, reversed the effect of a negative view of the United States. Under that condition, the probability of support for suicide attacks was between $0 \%$ and $33.1 \%$.

The case of Turkey, in the bottom right panel of Figure 4, differs from that of Jordan and Lebanon. U.S. soft power is not the primary variable in discriminating the patterns of support of suicide bombing attacks against Americans and Westerners. Instead, what made a difference was the presence of pro Al-Qaeda sentiments in conjunction with a negative view of the American people. Under this scenario, the probability of support for suicide attacks against Americans and Westerners ranged between 50.3\% and 74.5\%. Al-Qaeda sympathizers who like the American people, on the other hand, were less inclined to find suicide attacks justifiable.

But, as the size of the confidence intervals indicates, the impact of these factors is uncertain.

The analysis of the Turkish sample, thus, generates a worrisome finding: while there are fewer supporters of suicide bombing attacks among the Turkish people, their attitudes seem to be more deeply entrenched as they reflect extremist ideas such as having confidence in Al-Qaeda's late leader and viewing the people of the United States, an ally, in a negative light.

\section{ROBUSTNESS CHECKS}

The models in Figure 4 deliver important results for the theory of soft power. But how do they fit the data? To address this question, I proceed in two ways: (a) I compare the out-of-sample predictive ability of the CART models vs. logistic regression models; and (b) I replicate the analysis in Figure 4 using two alternative measures of attitudes towards suicide attacks.

I estimated the models using a training set three quarters of the size of the original sample. To assess the out-of-sample performance of the models on the test set, I employ a variant of the common classification tables used in parametric models with dichotomous dependent variables. These tables, which are usually called "CART confusion tables," tabulate the data against the classes predicted by the CART model (Berk 2008, 108-110). The classification table provides three pieces of information: (a) the overall out-of-sample error, i.e. the overall proportion of observations classified incorrectly, which is the figure underlined in the 
lower right corner of the table; (b) the model error, i.e. the proportion of observations incorrectly classified per observed class; and (c) the use error, i.e. the proportion of observations incorrectly classified per predicted class. Each number highlights a different aspect of how the CART model fits the data.

As I show in Table 1, compared to the logistic regression models (reported in Table II in the on-line Appendix), the CART models yield in all but one instance (i.e., Turkey) a lower overall error rate. Given that all the variables with the exception of Age were entered as factor variables, the logistic regression models included twenty four variables. In this case, the logistic regression models cannot match the simplicity and predictive power of the CART models.

Table 1. Out-of-Sample Model Fit

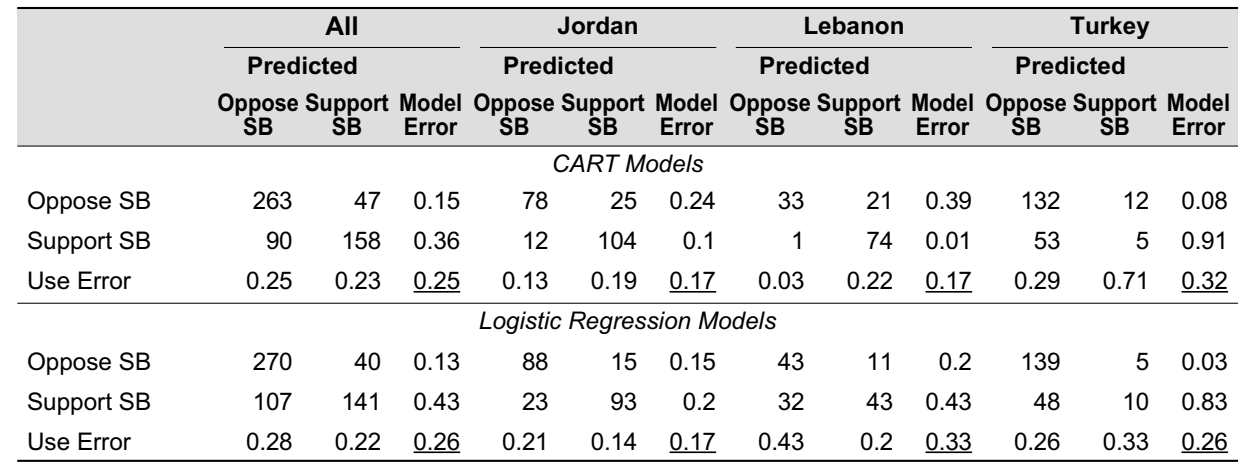

aData summarize the out-of-sample model fit of the CART models in Figure 4 and the logistic regression models in Table II (in the on-line Appendix), respectively. The figure underlined in the lower right corner represents the overall out-of-sample error rate; for example, $\frac{47+90}{263+47+90+158}=0.25$. Model error rates are computed as row percentages of observations misclassified; for example, $\frac{47}{47+263}=0.15$. Use error rates are computed as column percentages of observations misclassified; for example, $\frac{90}{90+263}=0.25$. SB stands for "suicide bombing against Americans and Westerners." Data analysis based on the 2005 wave of the Pew Global Attitudes Survey.

The Model Error, in the third column of each panel in Table 1, shows how likely the models are to misclassify an observation in a known class. In general, the CART models generate a larger number of "false positives," i.e. cases where the model predicts support for suicide bombing when the observation was actually coded as opposition to suicide bombing, than the logistic regression models. In all instances but Turkey, the CART models conversely generate a smaller number of "false negatives," i.e. observations coded as cases of support for suicide terrorism when they were cases of opposition. Column percentages, or Use Error rates, instead, show how often a prediction will be incorrect. For example, if we were to claim that a given respondent would oppose suicide bombing on the basis of the CART model, we would be incorrect $19 \%$ of the time in the Jordanian sample. 
Under logistic regression, that probability would be $14 \%$. Overall, then, we can conclude that the models in Figure 4 strike a good balance between their out-ofsample predictive ability, on the one hand, and their parsimony and interpretability (Berk 2008, 129-130).

I also replicate the analysis presented in Figure 4 using the two alternative measures of attitudes towards suicide attacks from Figures 2 and $3 .{ }^{13}$ As we saw, the form of the survey question makes a difference. Still, it is important to assess whether U.S. soft power affects beliefs about extremist strategies more generally.

In Figure 5, I report four CART models for the generic survey item that did not specify that the suicide attacks would occur in the respondent's country. ${ }^{14}$ Overall, the expectations of the soft power theory appear vindicated in the aggregate sample and, specifically, among Jordanians. In the aggregate case, in the top left panel, the model first distinguishes between Turkey, on the one hand, and Jordan and Lebanon, on the other; it then sorts Jordanians and Lebanese on the basis of their views of the United States. Only 8 (out of 91) individuals who were favorable to the United States approved of suicide attacks to defend Islam, which yields a posterior probability of support that ranges between $3.8 \%$ and $15.2 \%$. In Jordan, the most discriminating factor was also attitudes towards the United States, followed by people's views of France, as was the case in the models in Figure 4 .

\footnotetext{
${ }^{13}$ For more details, see footnote 7.

${ }^{14}$ In Table III in the on-line Appendix, I report an analysis of the out-of-sample performance of the models in Figures 5 and 6.
} 


\section{Figure 5. Attitudinal Profile of the Support for Suicide Bombing to Defend Islam}

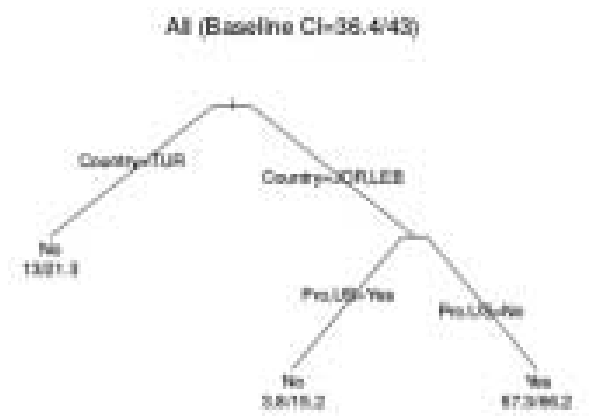

Lebonon (Bsedine $\mathrm{Cl}-37) 50.8$ )

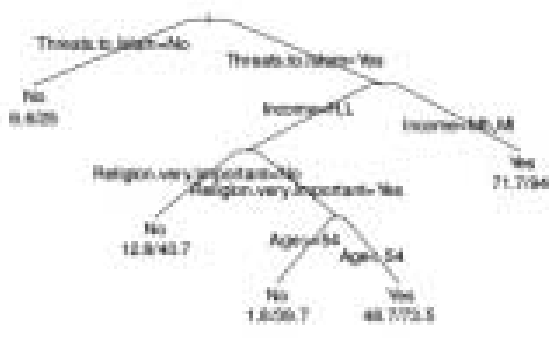

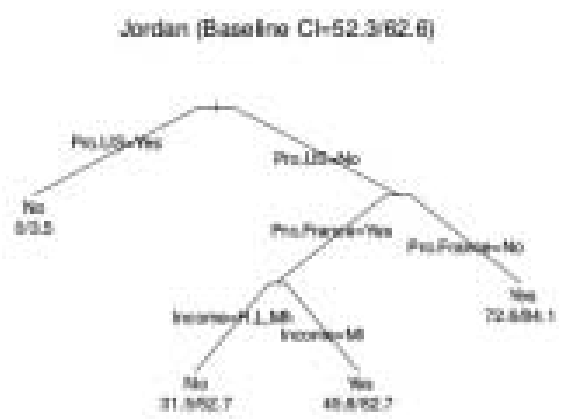

Tarkey (Baseine Cl=12.7/20.9)

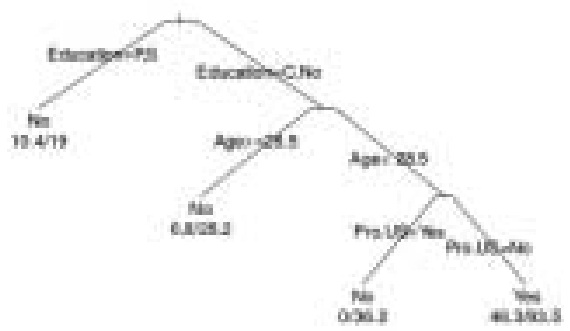

LEGEND:

EDUCATION

INCOME

PRO.FRANCE

PRO.US

RELIGION.VERY.IMPORTANT

THREATS.TO.ISLAM

$$
\begin{aligned}
& \mathrm{C}=\text { college; } \mathrm{S}=\text { =secondary; } \mathrm{P}=\text { =primary; } \mathrm{No}=\text { no education } \\
& \mathrm{H}=\text { =high; } \mathrm{Mh}=\text { =medium high; } \mathrm{Ml}=\text { =medium low; } \mathrm{L}=\mathrm{low} \\
& \text { Does respondent have a favorable opinion of France? } \\
& \text { Does respondent have a favorable opinion of the United States? } \\
& \text { Is religion very important in respondent's life? } \\
& \text { Does respondent believe that there are serious threats to Islam? }
\end{aligned}
$$

Note: Data analysis is based on the 2005 wave of the Pew Global Attitudes Survey, The labels below the final branches indicate the most common response: "No" indicates that the most common response was disapproval of suicide bombing; "Yes" indicates that the mmost common response was approval suicide bombing. The numbers underneath measure the $95 \%$ Bayesian confidence intervals around the conditional probability of approval of suicide bombing. "Cl" stands for Confidence Interval.

The Lebanese and Turkish cases differ, both in terms of the overall predictive ability of the model and in terms of the ordering of variables in the CART model. In Lebanon, the CART model finds evidence in support of the hypothesis linking a sense of ontological insecurity, i.e., the belief that there are serious threats to Islam, with support for suicide attacks. After that, the model finds a curvilinear effect for income. Substantively, support for suicide attacks to defend Islam is 
predominantly found in the Lebanese middle class who felt their identity as Muslims under threat. In the Turkish sample, the model identifies four groups: (a) those who have either a primary or a secondary level education; (b) those who have either no education or college education and are 29-years old or older; (c) those who have either no education or college education, are 28-years old or younger and have a positive view of the United States; and (d) those who have either no education or college education, are 28-years old or younger and have a negative view of the United States. Of these groups, only the last one is associated with a predicted probability of support for suicide attacks to defend Islam that does not overlap the baseline confidence interval. This finding reflects the difficult to identify the very few supports of suicide attacks in Turkey.

As we move away from survey items that explicitly identify Americans and Westerners as the targets in suicide attacks, the support for the soft power thesis diminishes. This trend continues for the section of the sample that received the survey experiment asking about suicide attacks in the country of the respondent. The mention of the location of the attacks not only changes propensity to find suicide attacks justifiable, as we saw in Figures 2 and 3, but also the underlying structure of the responses. The results from the CART models in Figure 6 indicate that, overall, the most discriminating factor to classify support for suicide attacks occurring in the country of the respondent was the fear that the United States might become a military threat to their countries. Still, in the case of Jordan and Lebanon, two soft power variables, i.e. views of the American people and of the United States, respectively, emerged as the most discriminating factors. 
Figure 6. Attitudinal Profile of the Support for Suicide Bombing in Your Country to Defend Islam

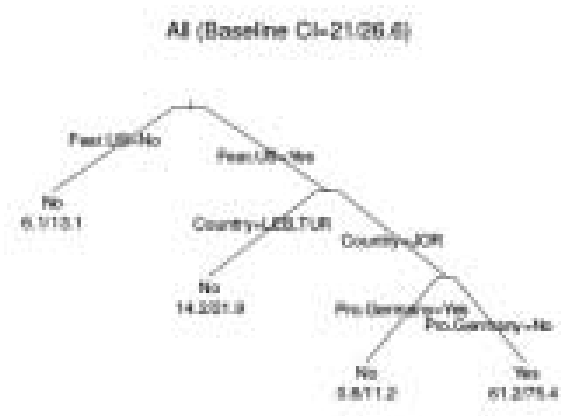

Lebanon (Baselne Chasas31)

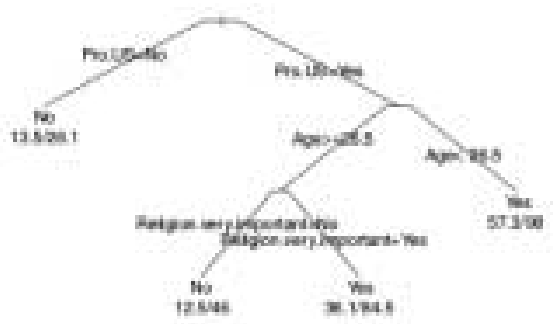

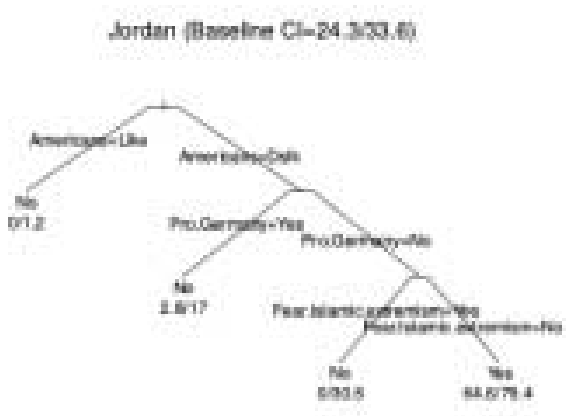

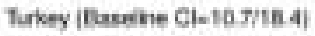

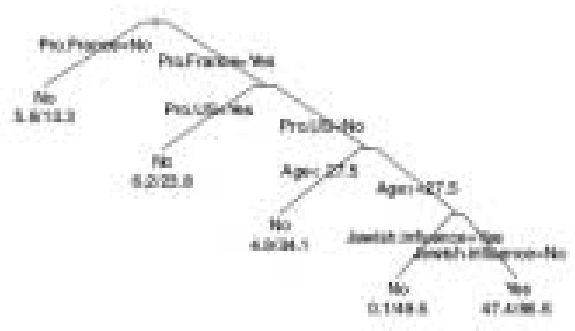

LEGEND:

AMERICANS

FEAR.ISLAMIC.EXTREMISM

FEAR.US

JEWISH.INFLUENCE

PRO.FRANCE

PRO.GERMANY

PRO.US

RELIGION.VERY.IMPORTANT

\author{
Dslk=Respondent dislikes the American people; Like=Repondent likes the American people \\ Does respondent fear Islamic extremism? \\ Does respondent believe that the United States might become a military threat to their country? \\ Do J ewish people have the most influence on U.S. foreign policy? \\ Does respondent have a favorable opinion of France? \\ Does respondent have a favorable opinion of Germany? \\ Does respondent have a favorable opinion of the United States? \\ Is religion very important in respondent's life?
}

Note: Data analysis is based on the 2005 wave of the Pew Global Attitudes Survey. The labels below the final branches indicate the most common response: "No" indicates that the most common response was disapproval of suicide bombing; "Yes" indicates that the most common response was approval suicide bombing. The numbers underneath measure the $95 \%$ Bayesian confidence intervals around the conditional probability of approval of suicide bombing. "Cl" stands for Confidence Interval.

Overall, then, the models in Figures 5 and 6 yield qualified support for the soft power thesis. This is more the case for the models where the dependent variable measured support for suicide bombings to defend Islam, with no reference to the location of the attacks. When respondents were asked to express their approval for suicide attacks in their countries, however, the models yield less consistent 
results. None of the alternative hypotheses in this study receive strong support. At most, it appears that suicide bombing attacks in one's own country would only resonate among people concerned that the United States might become a military threat to their countries.

\section{BEYOND 2005}

Approval for suicide bombing attacks has been declining since 2005, as I illustrate in Figure 7 where I plot the percentages of Jordanians, Lebanese, and Turks who found suicide bombing attacks to defend Islam justifiable. That is particularly the case in Jordan and Turkey, where support is well below 20\%, but less so in Lebanon where the percentage of support is anchored around 35\%. A direct replication of the findings from the models in Figure 4 is not possible, given that the survey question about support of suicide attacks against Americans and Westerners in Iraq was only asked in the 2005 wave of the Pew Global Attitudes Survey. Despite the qualifications that emerge from the previous analysis (see also Berger 2014), the general indicator about suicide attacks to defend Islam, however, is an acceptable approximation to assess the extent to which U.S. soft power may have contributed to these trends.

Figure 7. Support for Suicide Bombing to Defend ISlam, 2007-11
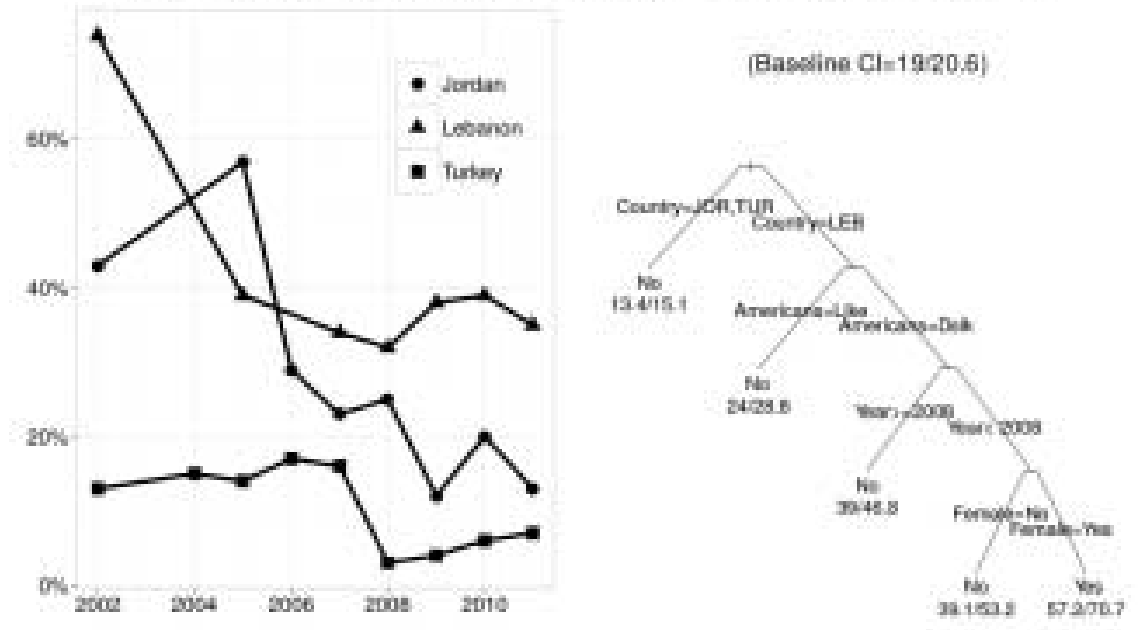

Note: Data analysis is based on the 2007, 2008, 2009, 2010, and 2011 waves of the Pew Global Attitudes Survey. The labels below the final branches indicate the most common response: "No" indicates that the most common response was disapproval of suicide bombing; "Yes" indicates that the most common response was approval of suicide bombing. The numbers underneath measure the $95 \%$ Bayesian confidence intervals around the conditional probability of approval of suicide bombing. 
To this effect, I combined the Pew Global Attitudes Surveys from 2007 to 2011 and estimated, using a validation set approach as before, a CART model which includes the predictors from the models in Figure 4 that were available in all five surveys. The results, in the right panel of Figure 7, show that Jordan and Turkey cluster together, with a probability of support for suicide attacks that ranges between $13.4 \%$ and $15.1 \%$. In the tree branch for Lebanon, three variables account for the patterns of support. One of those variables is the soft power variable measuring attitudes towards the American people; one measures gender; and one finds a temporal shift before and after 2008, which overall underscores the declining resonance of suicide attacks. Even in this case, then, the soft power thesis finds some corroboration in the views of the Lebanese people.

\section{CONCLUSIONS}

In this paper, I analyzed the reasons why ordinary people give approval to the suicide bombing strategy of extremist groups attacking Americans in Iraq. My analysis, which focuses on three countries in the immediate neighborhood of Iraq in 2005, illustrates how, in a period of serious crisis for the United States, the tactics of the extremists appealed to the mass publics. In such difficult conditions, where we would expect reactions to U.S. occupation of Iraq or U.S. support for Israel would shape people's beliefs, two measures of U.S. soft power, namely favorable views of the United States and the American people, were the most powerful predictors of opposition to suicide bombing attacks against Americans and Westerners in Iraq. The policy component of soft power, as measured by the endorsement of U.S. anti-terrorist policies, however, had no impact on views about suicide terrorism.

In the long standing controversy surrounding the security implications of soft power as a viable mechanism to obtain the compliance of political subjects, these findings clearly side with the soft power thesis. The engagement fostered by a positive image of the United States and the American people were associated with beliefs that were beneficial to the security and well-being of the United States. Strategies of reassurance about U.S. goals in the Middle East would help contain the radicalization of ordinary people.

These findings have implications for how the United States shapes its strategy to win hearts and minds in the Islamic world. Soft power is hardly a manipulable instrument of policy that can be deployed at the discretion of policy-makers (Gray 2011). But, as soft power and public diplomacy advocates maintain (Lord 2008; Nye 2011), it pays to promote a positive image of the United States and its peo- 
ple. But it also pays to reassure ordinary people in the Middle East that the United States is not an imperial and exploitative country, disdainful of the needs and interests of ordinary people in the region. Preposterous though they might seem for ordinary Americans, those fears shaped the collective imagination of large portions of the Islamic publics in a manner that was detrimental to the success of the United States in the war of ideas against Islamic radicalism. It will take time, energy, resources, commitment, and leadership to mend the distrust that surrounds the United States in the Middle East. But the United States should be mindful that when it was facing a serious crisis in Iraq in 2005, high popular standing delegitimized anti-American violence.

\section{REFERENCES}

Abrahms, Max. 2006. "Why Terrorism Does Not Work." International Security 31(2), 42-78.

Achen, Christopher H. 2005. "Let's Put Garbage-Can Regressions and GarbageCan Probits Where They Belong." Conflict Management and Peace Science 22(4), 327-339.

American Political Science Association. 2009. "US Standing in the World: Causes, Consequences, and the Future." Long Report of the Task Force on U.S. Standing in World Affairs, Accessed at http://www.apsanet.org/ media/PDFs/APSA_TF_USStanding_Long_Report.pdf.

Atkinson, Carol. 2010. "Does Soft Power Matter? A Comparative Analysis of Student Exchange Programs 1980-2006." Foreign Policy Analysis 6(1), 1-22.

. 2014. Military Soft Power: Public Diplomacy through Military Educational Exchanges. Lanham, MD: Rownan \& Littlefield.

Atran, Scott. 2006. "The Moral Logic and Growth of Suicide Terrorism." Washington Quarterly 29(2), 127-147.

BBC News. 2005. "Jordan Hotel Blasts Kill Dozens." Accessed at http://news.bbc.co.uk/2/hi/middle_east/44230o8.stm.

Berger, Lars. 2014. "Foreign Policies or Culture: What Shapes Muslim Public Opinion on Political Violence against the United States.” Journal of Peace Research: forthcoming.

Berinsky, Adam J. 2004. Silent Voices: Public Opinion and Political Participation in America. Princeton, NJ: Princeton University Press.

Berk, Richard A. 2004. Regression Analysis: A Constructive Critique. Thousand Oaks, CA: Sage Publications. 
. 2008. Statistical Learning from a Regression Perspective. New York: Springer.

Berman, Eli and David D. Laitin. 2006. "Hard Targets: Theory and Evidence on Suicide Attacks.” Paper available at http://econ.ucsd.edu/ elib/ Hardtargets.pdf.

Bloom, Mia. 2005. Dying to Kill: The Allure of Suicide Terror. New York: Columbia University Press.

Bueno de Mesquita, Ethan. 2005. "The Quality of Terror." American Journal of Political Science 49(3), 515-530.

. 2007. "Correlates of Public Support for Terrorism in the Muslim World." United States Institute of Peace, Working Paper.

Cáceres, Neila and Samuel W. Malone. 2013. "Forecasting Leadership

Transitions Around the World." International Journal of Forecasting 29(4), 575-591.

Chiozza, Giacomo. 2009. Anti-Americanism and the American World Order. Baltimore, MD: Johns Hopkins University Press.

Chiozza, Giacomo and Ajin Choi. 2012. "Going the American Way: The Surprising Case of Korean Pro-Americanism.” Pacific Review 25(2), 269-292.

Choi, Seung-Whan. 2010. "Fighting Terrorism through the Rule of Law?” Journal of Conflict Resolution 54(6), 940-966.

Cole, Juan. 2006. "Anti-Americanism: It's the Policies." American Historical Review 111(4), 1120-1129.

Cragin, Kim and Scott Gerwehr. 2005. Dissuading Terror: Strategic Influence and the Struggle against Terrorism. Santa Monica, CA: RAND.

Crenshaw, Martha. 2007. "Explaining Suicide Terrorism: A Review Essay." Security Studies 16(1), 133-162.

Datta, Monti Narayan. 2009. “The Decline of America's Soft Power in the United Nations." International Studies Perspectives 10(3), 265-284. . 2014. Anti-Americanism and the Rise of World Opinion. New York: Cambridge University Press.

de Marchi, Scott. 2005. Computational and Mathematical Modeling in the Social Sciences. New York: Cambridge University Press.

Enders, Walter and Todd Sandler. 2006. The Political Economy of Terrorism. New York: Cambridge University Press.

Fair, C. Christine and Bryan Shepherd. 2006. "Who Supports Terrorism? Evidence from Fourteen Muslim Countries." Studies in Conflict \& Terrorism 29(1), 51-74.

Friendly, Michael. 1999. "Visualizing Categorical Data." In Monroe G. Sirken, Douglas J. Herrmann, Susan Schechter, Norbert Schwarz, Judith M. 
Tanur and Roger Tourangeau ed., Cognition and Survey Research. New York: John Wiley \& Sons, 319-348.

Gambetta, Diego ed., 2005. Making Sense of Suicide Missions. New York: Oxford University Press.

Gambetta, Diego and Steffen Hertog. 2009. "Why Are There So Many Engineers among Islamic Radicals?" European Journal of Sociology 50(2), 201-230.

Gelpi, Christopher, Peter D. Feaver and Jason Reifler. 2005. "Success Matters: Casualty Sensitivity and the War in Iraq." International Security 30(3), 7-46.

Gleditsch, Kristian S. and Michael D. Ward. 1997. "Double Take: A Reexamination of Democracy and Autocracy in Modern Polities." Journal of Conflict Resolution 41(3), 361-383.

Goldsmith, Benjamin E. and Yusaku Horiuchi. 2012. "In Search of Soft Power: Does Foreign Public Opinion Matter for US Foreign Policy?” World Politics 64(3), 555-585.

Gould, Eric D. and Esteban F. Klor. 2010. “Does Terrorism Work?” Quarterly Journal of Economics 125(4), 1459-1510.

Gray, Colin. 2011. Hard Power and Soft Power: The Utility of Military Force as an Instrument of Policy in the 21st Century. Carlisle, PA: Strategic Studies Institute Monographs.

Hafez, Mohammed M. 2007. Suicide Bombers in Iraq: The Strategy and Ideology of Martyrdom. Washington, D.C.: United States Institute of Peace.

Harrell, Frank E., Jr. 2001. Regression Modeling Strategies: With Applications to Linear Models, Logistic Regression, and Survival Analysis. New York: Springer.

Hastie, Trevor, Robert Tibshirani and Jerome Friedman. 2001. The Elements of Statistical Learning: Data Mining, Inference and Prediction. New York: Springer.

Henne, Peter S. 2012. "The Ancient Fire: Religion and Suicide Terrorism." Terrorism and Political Violence 24(1), 38-60.

Hoffman, Bruce. 2006. Inside Terrorism. New York: Columbia University Press. Huntington, Samuel P. 1996. The Clash of Civilizations and the Remaking of World Order. New York: Simon \& Schuster.

James, Gareth, Daniela Witten, Trevor Hastie and Robert Tibshirani. 2013. An Introduction to Statistical Learning with Applications in R. New York: Springer.

Juergensmeyer, Mark. 2003. Terror in the Mind of God: The Global Rise of Religious Violence. Berkeley, CA: University of California Press.

Kalyvas, Stathis and Ignacio Sánchez-Cuenca. 2005. "Killing without Dying: The 
Absence of Suicide Missions." In Diego Gambetta ed., Making Sense of Suicide Missions. New York: Oxford University Press, 209-232.

Kastellec, Jonathan P. 2010. "The Statistical Analysis of Judicial Decisions and Legal Rules with Classification Trees.” Journal of Empirical Legal Studies 7(2), 202-230.

Kilcullen, David. 2009. The Accidental Guerrilla: Fighting Small Wars in the Midst of a Big One. New York: Oxford University Press.

Krueger, Alan B. 2007. What Makes a Terrorist: Economics and the Roots of Terrorism. Princeton, NJ: Princeton University Press.

Laitin, David D. and Jacob N. Shapiro. 2008. "The Political, Economic, and Organizational Sources of Terrorism." In Philip Keefer and Norman Loayza ed., Terrorism, Economic Development, and Political Openness. New York: Cambridge University Press, 209-232.

Layne, Christopher. 2010. "The Unbearable Lightness of Soft Power." In Inderjeet Parmar and Michael Cox ed., Soft Power and US Foreign Policy: Theoretical, Historical and Contemporary Perspectives. New York: Routledge, 51-82.

Lee, Alexander. 2011. "Who Becomes a Terrorist? Poverty, Education, and the Origins of Political Violence." World Politics 63(2), 203-245.

Lee, Peter M. 1997. Bayesian Statistics: An Introduction. Second ed. London: Arnold.

Lord, Kristin M. 2008. Voices of America: U.S. Public Diplomacy for the 21st Century. Washington, D.C.: Brookings.

Mitzen, Jennifer. 2006. "Ontological Security in World Politics: State Identity and the Security Dilemma." European Journal of International Relations 12(3), 341-370.

Moghadam, Assaf. 2006. "The Roots of Suicide Terrorism: A Multi-Causal Approach." In Ami Pedahzur ed., Root Causes of Suicide Terrorism: The Globalization of Martyrdom. New York: Routledge, 81-107.

Mueller, John. 1971. "Trends in Popular Support for the Wars in Korea and Vietnam." American Political Science Review 65(2), 358-375.

Nye, Joseph S., Jr. 2011. The Future of Power. New York: Public Affairs.

O’Rourke, Lindsey A. 2009. "What's Special about Female Suicide Terrorism?" Security Studies 18(4), 681-718.

Pape, Robert A. 2005. Dying to Win: The Strategic Logic of Suicide Terrorism. New York: Random House.

Parmar, Inderjeet and Michael Cox eds., 2010. Soft Power and US Foreign Policy: Theoretical, Historical and Contemporary Perspectives. New York: Routledge. 
Pedahzur, Ami. 2005. Suicide Terrorism. Malden, MA: Polity Press.

Pedahzur, Ami and Arie Perliger. 2006. "Introduction: Characteristics of Suicide Attacks." In Ami Pedahzur ed., Root Causes of Suicide Terrorism: The Globalization of Martyrdom. New York: Routledge , 1-12.

Pew Global Attitudes Project. 2005. "Islamic Extremism: Common Concern for Muslim and Western Publics." Technical report The Pew Research Center for the People \& the Press Available at http://pewglobal.org/reports/pdf/ 248.pdf.

Piazza, James A. 2008. "A Supply-Side View of Suicide Terrorism: A CrossNational Study." Journal of Politics 70(1), 28-39.

Pipes, Daniel. 2002. "A New Round of Anger and Humiliation: Islam after 9/11." In Wladyslaw Pleszczynski ed., Our Brave New World: Essays on the Impact of September 11. Stanford, CA: Hoover Institution Press, 41-61.

Rasler, Karen, Eli Berman and David Laitin, Roxanne L. Euben, Ian Shapiro and Gilles Kepel. 2007. "Review Symposium: Understanding Suicide Terror.” Perspectives on Politics 5(1), 118-140.

Ricks, Thomas E. 2006. Fiasco: The American Military Adventure in Iraq. New York: Penguin Press.

Rubin, Barry. 2002. "The Real Roots of Arab Anti-Americanism." Foreign Affairs $81(6), 73-85$.

Shafiq, M. Najeeb and Abdulkader H. Sinno. 2010. "Education, Income and Support for Suicide Bombings: Evidence from Six Muslim Countries." Journal of Conflict Resolution 54(1), 146-178.

Shanker, Thom. 2010a. "Joint Chiefs Chairman Readjusts Principles on Use of Force.” New York Times (March 3).

Shanker, Thom. 2010b. "Top U.S. Commander Sees Progress in Afghanistan." New York Times (February 4).

Simon, Steven and Jeff Martini. 2004. "Terrorism: Denying Al Qaeda Its Popular Support." Washington Quarterly 28(1), 131-145.

Stern, Jessica. 2003. Terror in the Name of God: Why Religious Militants Kill. New York: Ecco.

Tessler, Mark and Michael D. H. Robbins. 2007. "What Leads Some Ordinary Arab Men and Women to Approve of Terrorist Acts Against the United States." Journal of Conflict Resolution 51(2), 305-328.

Therneau, Terry M. and Elizabeth J. Atkinson. 1997. "An Introduction to Recursive Partitioning Using RPART Routines.” Technical Report \# 61; Department of Health Science Research, Mayo Clinic, Rochester, MN; Accessed at http://www.mayo.edu/hsr/techrpt/61.pdf.

Tukey, John W. 1969. “Analyzing Data: Sanctification or Detective Work?” 
American Psychologist 24(2), 83-91.

United States Department of State. 2004. "Patterns of Global Terrorism, 2003." Washington, D.C.; Accessed at http://www.state.gov/documents/organization/31932.pdf.

U.S. Army/Marine Corps. 2007. Counterinsurgency Field Manual. Chicago, IL: University of Chicago Press.

Victoroff, Jeff. 2005. "The Mind of the Terrorist: A Review and Critique of Psychological Approaches.” Journal of Conflict Resolution 49(1), 3-42. Waterbury, John. 2003. "Hate Your Policies, Love Your Institutions." Foreign Affairs 82(1), 58-68.

Weinberg, Leonard and Ami Pedahzur. 2003. Political Parties and Terrorist Groups. London: Routledge.

Yetiv, Steve A. 2011. The Petroleum Triangle: Oil, Globalization, and Terror. Ithaca, NY: Cornell University Press.

Zorn, Christopher. 2005. "A Solution to Separation in Binary Response Models." Political Analysis 13(2), 157-170.

[Received J une 30, 2014; Revised August 24, 2014; Accepted September 3, 2014] 